\title{
Phenetic Study on Clustered Pinanga of Java and Bali
}

\author{
JOKO R. WITONO \\ Center for Plant Conservation, Bogor Botanical Gardens - LIPI, Bogor 16003
}

Received: 2 December 2002. Accepted: 1 January 2003

\begin{abstract}
The objective of the study was to know relationships of clustered Pinanga of Java and Bali based on morphological characters. Observation was done to 115 clustered Pinanga specimens ( $P$. coronata), 18 of which were assigned as Operational Taxonomic Units (OTUs). The morphological characters noted, analyzed using versions of the numerical taxonomy system / NTSYS version 1.80, 1993. The phenogram presents that clustered Pinanga of Java and Bali divided into two groups (clusters): specimens from lowland forest $(0-750 \mathrm{~m}$ asl) and specimens from montane forest (750 $\mathrm{m}$ asl or more). The cluster division is not dependent on the geographical distribution of the OTUs, but rather altitudes.
\end{abstract}

(c) 2003 Jurusan Biologi FMIPA UNS Surakarta

Key words: Java, Bali, NTSYS, OTUs, clustered Pinanga, phenetic study.

\section{INTRODUCTION}

Indonesia has the richest Pinanga in the world. This genus consists of about 120 species, 40 species of which are represented in Indonesia (Uhl and Dransfield, 1987; Mogea, 1991). In Java and Bali, there are 3 species of Pinanga namely $P$. javana, $P$. arinasae, and $P$. coronata. $P$. javana and $P$. arinasae are single stemmed. A third species, $P$. coronata is clustered. $P$. coronata is found throughout Java and Bali, occuring on very steep hillsides in montane forest and flat areas in lowland forest, from sea level $101800 \mathrm{~m}$ asl (Witono et al., 2002).

Clustered palms is what Holttum (1955) referred to as a sympodial habit, which he considered characteristic of monocotyledones. Each new shoot develops from an axillary bud, which in palms is usually located near the base of the stem. As each short then subsequently produces a new axillary shoot, a clustered habit results (Uhl and Dransfield, 1987). Clustered Pinanga usually has many small and short stems.

Classification has been defined as the ordering of organisms into groups on the basis of their relationships. The relationships may be genetic, evolutionary (phylogenetic), or may simply refer to similarities of phenotype (phenetic) (Dunn and Everitt, 1982). Phenetic classification is a construction relationships based on overall similarity of taxa (Sneath and Sokal, 1973) or presence and absence of characters. The phenetic arrangement of the taxa is developed with numerical procedures applied to the

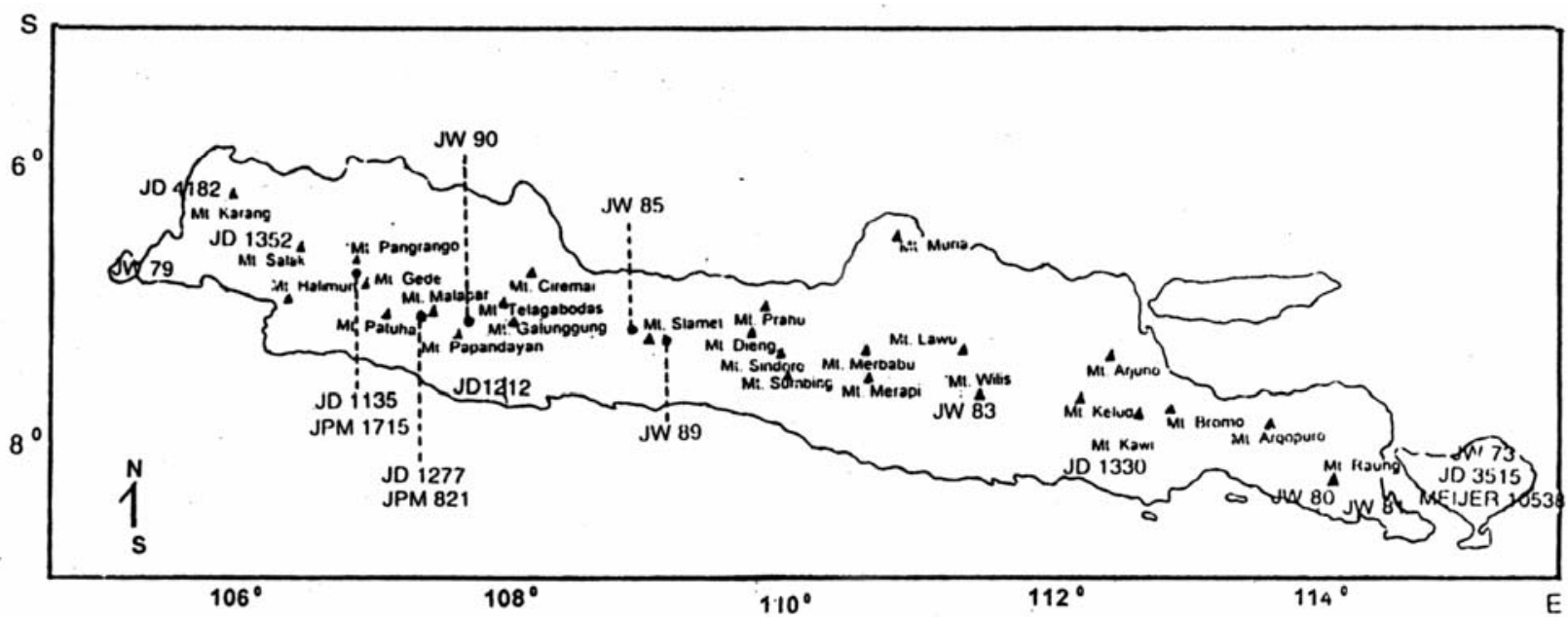

Figure 1. Geographical localities of clustered Pinanga of Java and Bali used in this study. 
Table 1. Specimens, localities, and altitudes of the clustered Pinanga used in this study.

\begin{tabular}{|c|c|c|c|}
\hline No. & Collector & Locality & Altitude (m) \\
\hline 1. & JW 79 & Cibunar, Ujung Kulon National Park, Pandeglang, West Java & 40 \\
\hline 2. & JD 1212 & Cibalanak, Cipatujah, Tasikmalaya, West Java & 30 \\
\hline 3. & JW 80 & Bande Alit, Meru Betiri National Park, Jember, East Java & 340 \\
\hline 4. & JW 81 & Pantai Penyu, Meru Betiri National Park, Sukamade, Banyuwangi, East Java & 60 \\
\hline 5. & JD 1330 & Ngliyep, south of Malang, East Java & 2 \\
\hline 6. & JD 4182 & Mt. Pulasari, Mandalawangi, Pandeglang, West Java & 500 \\
\hline 7. & JW 90 & Bukit Himalaya Nature Reserve, Sukamulya, Garut, West Java & 1,300 \\
\hline 8. & JD 1135 & Rawah Denok, Gede Pangrango National Park, Cibodas, West Java & 1,800 \\
\hline 9. & JPM 1715 & Kandang Badak, Gede Pangrango National Park, Cibodas, West Java & 1,700 \\
\hline 10. & JD 1352 & Mt. Salak, above Ciomas, Bogor, West Java & 1,500 \\
\hline 11. & JD 3515 & Bukit Tapak, Batukahu Nature Reserve, Bedugul, Bali & 1,000 \\
\hline 12. & Meijer 10538 & Bratan Lake, Bedugul, Bali & 1,000 \\
\hline 13. & JW 73 & Bukit Tapak, Batukahu Nature Reserve, Bedugul, Bali & 1,100 \\
\hline 14. & JD 1277 & Situ Patengang, Ciwideuy, Bandung, West Java & 1,400 \\
\hline 15. & JPM 821 & Cadas Panjang, Cimanggu, Bandung, West Java & 1,750 \\
\hline 16. & JW 83 & Alas Tiwang, Mt. Wilis, Kediri, East Java & 1,200 \\
\hline 17. & JW 85 & Pancuran Tujuh, Mt. Slamet, Purwokerto, Central Java & 750 \\
\hline 18. & JW 89 & Goa Lawa, Mt. Slamet, Purbalingga, Central Java & 800 \\
\hline
\end{tabular}

Table 2. Morphological characters used in phenetic study.

\begin{tabular}{|c|c|}
\hline No. & Characters \\
\hline & Vegetative Structures \\
\hline 1. & Colour of crownshaft: green brownish (2), green yellowish (1), green (0) \\
\hline 2. & Petiole and rachis surface silvery indumentum: present (1), absent (0) \\
\hline 3. & Number of leaflets on each side of rachis: 21 leaflets or more (2), $11-20$ leaflets (1), $0-10$ leaflets (0) \\
\hline 4. & Ratio length to width of basal leaflets: 41 or more (2), $26-40$ (1), $0-25$ (0) \\
\hline 5. & Ribs number of basal leaflets: 3 or more (2), 2 (1), 1 (0) \\
\hline 6. & Ratio length to width of middle leaflets: 21 or more (2), $13-20(\mathbf{1}), 0-12(\mathbf{0})$ \\
\hline 7. & ribs number of middle leaflets: 4 or more (2), $3(1), 1-2(0)$ \\
\hline 8. & Ratio length to width of topmost leaflets: 12.6 or more $(2), 7.6-12.5(1), 0-7.5(0)$ \\
\hline 9. & ribs number of topmost leaflets: 7 or more (2), $5-6(1), 1-4(0)$ \\
\hline & Inflorescence Structures \\
\hline 10. & Growth form of inflorescence: pendulous (1), erect then pendulous (0) \\
\hline 11. & Order branches at basal rachillae: 2 orders (1), 1 order $(\mathbf{0})$ \\
\hline 12. & Sepal form of female flower: orbicularis (1), broad orbicularis (0) \\
\hline 13. & Petal form of female flower: orbicularis (1), broad orbicularis (0) \\
\hline 14. & Fruit form: ellipsoid (2), ovoid (1), obovoid (0) \\
\hline
\end{tabular}

character states of organisms under study. Sneath and Sokal (1986) mentioned this method as numerical taxonomy or taxometrics (Stace, 1989).

A major approach to analyzing similarities and dissimilarities in this study is cluster analysis. There are three widely applied agglomerative clustering methods, but only one of them is employed in this study. The three methods are: single-linkage clustering, complete-linkage clustering, and groupaverage clustering (Dunn and Everitt, 1982). Groupaverage clustering analysis will be the applied agglomerative clustering method employed in this study.

This phenetic study is to provide a natural classification for the clustered Pinanga of Java and Bali based on morphological characters. The result of this study is phenogram or relationship of the clustered Pinanga of Java and Bali from many localities, altitudes, and habitats.

\section{MATERIALS AND METHODS}

\section{Plant materials}

In this study, all herbarium specimens of clustered Pinanga at Herbarium Bogoriense were observed. The number of collection of clustered Pinanga of Java and Bali are 115 specimens, 18 of which were assigned as Operational Taxonomic Units (OTUs) which are shown in Table 1 and the geographical localities of these specimens used in phenetic study are shown on Figure 1.

\section{Procedures}

The Morphological characters used in this study include vegetative structures (stem and leaves) and inflorescence structures. Fourteen morphometric characters (Table 2.) were chosen. These included seven qualitative and seven quantitative characters. 
Nine characters were recognized from vegetative structures and five from the inflorescence structures. While qualitative characters were ordered and assigned numerical codes, quantitative characters were entered directly as raw data.

Data processing was carried out using versions of the numerical taxonomy system / NTSYS. NTSYS is a system of programs that is used to find and display structure in multivariate data. This system can be used to compute various measures of similarity or dissimilarity between all pairs of objects and then summarize the information either in terms of noted sets of similar objects (Rohlf, 1993).

The results are expressed in an OTU by OTU dissimilarity or similarity matrix. In the following stage, SAHN (Sequential, Agglomerative, Hierarchical, and Nested) clustering program was used to construct the phenogram. In this study used to UPGMA (unweighted pair-group method using averages).

\section{RESULTS AND DISCUSSIONS}

The raw data were converted to a matrix (Table 3.). The numerical taxonomy system produces value of correlation coefficients (Table 3.) and a phenogram (Figure 2.) which shows a relationship among the specimens of clustering Pinanga in Java and Bali with the specimens observed arrangement as shown in Table 1.

The phenogram presents that there are 16 levels of correlation coefficients, from tle lowest $(0.289)$ to the highest (1.000)(Matrix 2.). The lowest correlation coefficient indicates the less similar, and the highest is the closests similarity.

Whitmore (1985) divided the forest formations of the tropical Far East into three types: lowland forest (1-750 m asl), lower montane forest (750-1500 m asl), and upper montane forest (1500 $\mathrm{m}$ asl or more). The phenogram presents that clustered Pinanga from Java and Bali consists of two groups (clusters): specimens from lowland forest (JW 79, JD 1212, JW 80, JW 81, JD 1330, and JD 4182) and specimens from montane forest (JW 90, JD 1135, JPM 1715, JD 1352, JD 3515, MEIJER 10538, JW 73, JD 1277, JPM 821, JW 83, JW 85, and JW 89).

The second cluster are divided into two subclusters based on a value correlation coefficient 0,375 , there are specimens from the altitude $1000 \mathrm{~m}$ asl or more (JW 90, JD 1135, JPM 1715, JD 1352, JD 3515, MEIJER 10538, JW 73, JD 1277, JPM 821, and JW 83) and specimens from the altitude $1000 \mathrm{~m}$ or less (JW 85 and JW 89). Specimens JW 85 and JW 89 have different subcluster with the other specimens from montane forest, because part of their characters have similar to first cluster. There are number of leaflets on each side of rachis 11-20, rib number of basal leaflets 3 or more (JW 85) and 2 (JW 89), rib number of the middle leaflets 4 or more (JW 85) and 3 (JW 89), and rib number of apical leaflets 7 or more. The correlation coefficients between OTUs, subclusters, and clusters of clustered Pinanga are shown in Table 4.

These clusters are morphologically closely related. The cluster division is not dependent on the geographical distribution of the OTUs, but rather altitudes. So, the adaptation of clustered Pinanga in Java and Bali is vertically.

The species concept that continues to be used in describing palms is not only based on morphological similarities, but other factors such as ecology and geography are so important. In clustered Pinanga in Java and Bali, the main factors that caused display a wide variability in morphological characters is ecology, primarily temperature and light intensity.

Table 3. Morphological characters specimens of clustered Pinanga used in this study.

\begin{tabular}{|c|c|c|c|c|c|c|c|c|c|c|c|c|c|c|c|}
\hline No. & Specimens & 1 & 2 & 3 & 4 & 5 & 6 & 7 & 8 & 9 & 10 & 11 & 12 & 13 & 14 \\
\hline 1. & JW 79 & 2 & 1 & 0 & 0 & 2 & 0 & 2 & 0 & 2 & 1 & 0 & 0 & 0 & 0 \\
\hline 2. & JD 1212 & 2 & 1 & 1 & 0 & 2 & 0 & 2 & 0 & 2 & 1 & 1 & 0 & 1 & 0 \\
\hline 3. & JW 80 & 2 & 1 & 2 & 2 & 0 & 0 & 1 & 0 & 2 & 1 & 0 & 1 & 1 & 0 \\
\hline 4. & JW 81 & 2 & 1 & 2 & 0 & 1 & 0 & 1 & 0 & 2 & 1 & 0 & 1 & 1 & 0 \\
\hline 5. & JD 1330 & 2 & 1 & 1 & 0 & 1 & 0 & 2 & 0 & 2 & 1 & 0 & 1 & 1 & 2 \\
\hline 6. & JD 4182 & 2 & 1 & 0 & 1 & 0 & 1 & 2 & 0 & 2 & 1 & 1 & 0 & 1 & 2 \\
\hline 7. & JW 90 & 1 & 0 & 2 & 0 & 0 & 2 & 0 & 1 & 1 & 0 & 0 & 0 & 1 & 2 \\
\hline 8. & JD 1135 & 1 & 0 & 2 & 2 & 0 & 2 & 0 & 0 & 0 & 0 & 0 & 0 & 1 & 1 \\
\hline 9. & JPM 1715 & 1 & 0 & 2 & 1 & 0 & 2 & 0 & 0 & 0 & 0 & 0 & 0 & 1 & 2 \\
\hline 10. & JD 1352 & 0 & 0 & 2 & 1 & 0 & 2 & 0 & 0 & 0 & 0 & 0 & 1 & 1 & 2 \\
\hline 11. & JD 3515 & 0 & 0 & 2 & 1 & 0 & 2 & 0 & 1 & 0 & 0 & 0 & 1 & 1 & 1 \\
\hline 12. & MEIJER 10538 & 0 & 0 & 2 & 1 & 0 & 2 & 0 & 1 & 0 & 0 & 0 & 1 & 1 & 1 \\
\hline 13. & JW 73 & 0 & 0 & 2 & 1 & 0 & 1 & 0 & 2 & 0 & 0 & 0 & 1 & 1 & 1 \\
\hline 14. & JD 1277 & 2 & 0 & 2 & 2 & 0 & 2 & 0 & 1 & 0 & 0 & 0 & 0 & 0 & 2 \\
\hline 15. & JPM 821 & 2 & 0 & 2 & 1 & 0 & 1 & 0 & 0 & 0 & 0 & 0 & 0 & 0 & 2 \\
\hline 16. & JW 83 & 1 & 0 & 2 & 2 & 1 & 2 & 0 & 2 & 0 & 1 & 0 & 1 & 1 & 2 \\
\hline 17. & JW 85 & 1 & 0 & 1 & 0 & 2 & 0 & 2 & 0 & 2 & 0 & 1 & 1 & 1 & 2 \\
\hline 18. & JW 89 & 1 & 0 & 1 & 1 & 1 & 1 & 1 & 1 & 2 & 0 & 0 & 1 & 0 & 2 \\
\hline
\end{tabular}


Table 4. The correlation coefficients between OTUs, subclusters, and clusters of clustered Pinanga.

\begin{tabular}{|c|c|c|}
\hline Cc. & Value & Notes \\
\hline 16 & 1,000 & Similar character between JD 3515 and Meijer 10538 \\
\hline 15 & 0,929 & $\begin{array}{l}\text { Colour of crownshaft green yellowish, sepal form of female flower broad orbicularis (JPM 1715) vs } \\
\text { colour of crownshaft green, sepal form of female flower orbicularis (JD 1352) }\end{array}$ \\
\hline 14 & 0,927 & $\begin{array}{l}\text { Ratio length to width of middle leaflets } 13-20 \text {, ratio length to width of topmost leaflets } 12.6 \text { or more (JW } \\
\text { 73) vs ratio length to width of middle leaflets } 21 \text { or more, ratio length to width of topmost leaflets } 7.6-12.5 \\
\text { (JD } 3515, \text { MEIJER 10538) }\end{array}$ \\
\hline 13 & 0,857 & $\begin{array}{l}\text { Number leaflets on each side of rachis } 21 \text { or more, ribs number of middle leaflets } 3 \text {, fruit obovoid (JW } \\
81 \text { ) vs number leaflets on each side of rachis } 10-20 \text {, ribs number of middle leaflets } 4 \text { or more, fruit } \\
\text { ellipsoid (JD 1330) }\end{array}$ \\
\hline 12 & 0,823 & $\begin{array}{l}\text { Ratio length to width of basal leaflets } 41 \text { or more, fruit ovoid (JD 1135) vs ratio length to width of basal } \\
\text { leaflets } 26-40 \text {, fruit ellipsoid (JPM } 1715, \text { JD 1352) }\end{array}$ \\
\hline $11 \mathrm{a}$ & 0,786 & $\begin{array}{l}\text { Ratio length to width of basal leaflets } 41 \text { or more, ribs number of basal leaflets } 1 \text { (JW 80) vs ratio length } \\
\text { to width of basal leaflets } 0-25 \text {, ribs number of basal leaflets } 2 \text { (JW 81, JD 1330) }\end{array}$ \\
\hline $11 b$ & 0,786 & $\begin{array}{l}\text { Number leaflets on each side of rachis } 0-10 \text {, basal rachillae } 1 \text { order, petal form of pistillate flower broad } \\
\text { orbicularis (JW 79) vs number leaflets each side of rachis } 11-20 \text {, basal rachillae } 2 \text { orders, petal form of } \\
\text { pistillate flower orbicularis (JD 1212) }\end{array}$ \\
\hline 10 & 0,738 & $\begin{array}{l}\text { Ratio length to width of topmost leaflets } 7.6-12.5 \text {, ribs number of topmost leaflets } 5-6 \text { (JW 90) vs ratio } \\
\text { length to width of topmost leaflets } 0-7.5 \text {, ribs number of topmost leaflets } 1-4 \text { (JD 1135, JPM 1715, JD } \\
\text { 1352) }\end{array}$ \\
\hline 9 & 0,714 & $\begin{array}{l}\text { Ratio length to width of basal leaflets } 41 \text { or more, ratio length to width of middle leaflets } 21 \text { or more, ratio } \\
\text { length to width of topmost leaflets } 7.6-12.5 \text { (JD 1277) vs Ratio length to width of basal leaflets } 26-40 \text {, } \\
\text { ratio length to width of middle leaflets } 13-20 \text {, ratio length to width of topmost leaflets } 0-7.5 \text { (JPM 821) }\end{array}$ \\
\hline 8 & 0,708 & $\begin{array}{l}\text { Colour of crownshaft green yellowish, sepal form of pistillate flower broad orbicularis (JW 90, JD } 1135 \text {, } \\
\text { JPM 1715), fruit ellipsoid (JW 90, JPM 1715, JD 1352) vs colour of crownshaft green, sepal form of } \\
\text { pistillate flower orbicularis, fruit ovoid (JD 3515, JW 73, MEIJER 10538) }\end{array}$ \\
\hline 7 & 0,622 & $\begin{array}{l}\text { Petal form of female flower orbicularis (JW 90, JD 1135, JPM 1715, JD 1352, JD 3515, MEIJER 10538, } \\
\text { JW 73) vs petal form of female flower broad orbicularis (JD 1277, JPM 821) }\end{array}$ \\
\hline 6 & 0.619 & $\begin{array}{l}\text { Ribs number of middle leaflets } 4 \text { or more, sepal form of pistillate flower broad orbicularis (JW } 79 \text {, JD } \\
\text { 1212) vs ribs number of middle leaflets } 3 \text { (JW 80, JW 81), sepal form of pistillate flower orbicularis (JW } \\
80, \text { JW 81, JD 1330) }\end{array}$ \\
\hline 5 & 0.571 & $\begin{array}{l}\text { Ribs number of basal leaflets } 1 \text {, growth form of inflorescence erect then pendulous (JW 90, JD } 1135 \text {, } \\
\text { JPM 1715, JD 1352, JD 3515, MEIJER 10538, JW 73, JD 1277, JPM 821) vs ribs number of basal } \\
\text { leaflets 2, growth of inflorescence pendulous (JW 83) }\end{array}$ \\
\hline 4 & 0.543 & $\begin{array}{l}\text { Ratio length to width of middle leaflets } 0-12 \text { (JW 79, JD 1212, JW 80, JW 81, JD 1330) vs ratio length to } \\
\text { width of middle leaflets 13-20 (JD 4182) }\end{array}$ \\
\hline 3 & 0.500 & $\begin{array}{l}\text { Ratio length to width of basal leaflets } 0-25 \text {, ribs number of basal leaflets } 3 \text { or more, ratio length to width } \\
\text { of middle leaflets } 0-12 \text {, ribs number of middle leaflets } 4 \text { or more, ratio length to width of topmost leaflets } \\
0-7.5 \text {, basal rachillae branches } 1 \text { order, petal form of female flower orbicularis (JW 85) vs Ratio length to } \\
\text { width of basal leaflets } 26-40 \text {, ribs number of basal leaflets } 2 \text {, ratio length to width of middle leaflets } 13- \\
20 \text {, ribs number of middle leaflets } 3 \text {, ratio length to width of topmost leaflets } 7.6-12.5 \text {, basal rachillae } \\
\text { branches } 2 \text { orders, petal form of female flower broad orbicularis (JW 89) }\end{array}$ \\
\hline 2 & 0.375 & $\begin{array}{l}\text { Number leaflets on each side of rachis } 21 \text { or more (JW 90, JD 1135, JPM 1715, JD 1352, JD 3515, } \\
\text { MEIJER 10538, JW 73, JD } 1277 \text {, JPM } 821 \text {, JW 83), ribs number of topmost leaflets } 1-4 \text { (except JW 90) } \\
\text { vs number leaflets on each side of rachis } 11-20 \text {, ribs number of topmost leaflets } 7 \text { or more (JW } 85, \text { JW } \\
\text { 89) }\end{array}$ \\
\hline 1 & 0.289 & $\begin{array}{l}\text { Petiole and rachis surface silvery indumentum, growth of inflorescence pendulous (JW 79, JD 1212, JW } \\
80 \text {, JW 81, JD 1330, JD 4182) vs petiole and rachis surface silvery indumentum: absent (JW 90, JD } \\
1135, \text { JPM 1715, JD 1352, JD 3515, MEIJER 10538, JW 73, JD 1277, JPM 821, JW 83, JW 85, JW 89), } \\
\text { growth of inflorescence erect then pendulous (except JW 83) }\end{array}$ \\
\hline
\end{tabular}




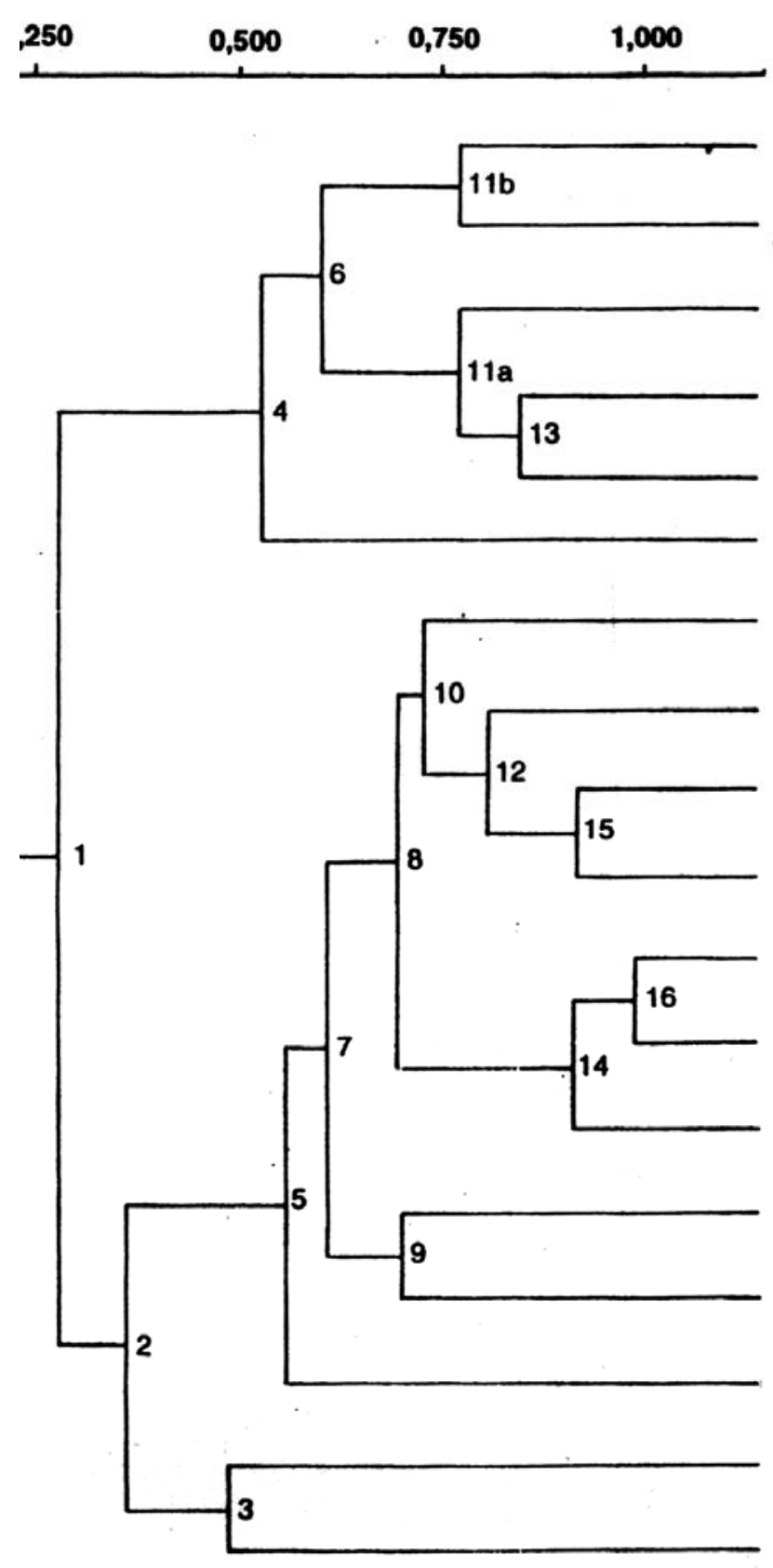

JW 79

(Ujung Kulon National Park, Pandeglang. West Java, $40 \mathrm{~m}$ ) JD 1212

(Cibalanak, Cipatujah, Tasikınalaya West Java, $30 \mathrm{~m}$ )

JW 80

(Meru Botiri National Park, Jember East Java, $340 \mathrm{~m}$ )

JW 81

(Meru Betiri National Park. Banyuwangi, East Java, $60 \mathrm{~m}$ ) JD 1330

(Ngltyep, Malang. East Java, 2 m) JD 4182

(Mi. Pulasari, Manklalawangi, Pandeglang. West Java, 500 m) JW 90

(Bukit Himalaya Nalure Reserve. Garut, West Java, $1.300 \mathrm{~m}$ ) JD 1135

(Gedo-Pangrango National Paık. Cibodas, West Java, $1,800 \mathrm{~m}$ )

JPM 1715

(Gede-Pangrango National Park. Cibodas. West Java, $1.700 \mathrm{~m}$ )

JD 1352

(Mt. Salak. Ciomas. Bogor. West

Java, $1.500 \mathrm{~m}$ )

JD 3515

(Bukit Tapak, Batukahu Nature

Reserve, Beduyul, Bali, $1.000 \mathrm{~m}$ )

MEIJER 10538

(Bratiun L.iaku. Berlingul, Biali,

$1.000 \mathrm{~m}$ )

JW 73

(Bukit Tapak. Batukahu Nature

Reserve, Bedugul, Bali, 1.100 in)

JD 1277

(Situ Patengang, Ciwideury.

Banding. West Javai, $1.400 \mathrm{~m}$ )

JPM 821

(Cadas Panjang, Cimanggu.

Bandung. West Java. $1.750 \mathrm{~m}$ )

JW 83

(Alas Tiwang, Mt. Wilis, Kediri,

East Java, $1.200 \mathrm{~m}$ )

JW 85

(Pancuran Tujuh, Mt. Slamet.

Purwokerto. Central Java. 750 (n) JW 89

(Goa Lawa, Mt. Slannet.

Purbalingga, Central Java, 800 in)

\section{CONCLUSIONS}

Based on phenetic analysis using UPGMA, it can be concluded that the clustered Pinanga of Java and Bali which observed divided into two groups (clusters): specimens from lowland forest $(0-750 \mathrm{~m}$ asl) and specimens from montane forest $(750 \mathrm{~m}$ asl or more). The second cluster are divided into two subclusters based on a value correlation coefficient 0,375 , there are specimens from the altitude $1000 \mathrm{~m}$ asl or more and specimens from the altitude $1000 \mathrm{~m}$ or less. The cluster division is not dependent on the geographical distribution of the OTUs, but rather altitudes.

\section{ACKNOWLEDGMENTS} This work was
supported by the
Montgomery Botanical
Center, Miami, Florida,
USA, through the
Indonesian Gardens, to which I am grateful. Thanks also given to the Director of Herbarium BogorienseLIPI, Himmah Rustiami, Dr. Johanis P. Mogea, Prof. Dr. S. Somadikarta, Dr. John Dransfield, Dr. Terrence W Walters, Dr. Larry R Noblick who gave their time to discuss various aspects of this study.

Figure 2. Phenogram of clustered Pinanga from Java and Bali.

\section{REFERENCES}

Dunn, G and Everitt, B.S. 1982. An introduction to mathematical taxonomy. Cambridge University Press, Cambridge: $x+152 p$.

Holttum, R.E. 1955. Growth-habits of monocotyledones-variation on a theme. Phytomorphology 5: 399-413.

Mogea, J.P.M. 1991. Indonesia: Palm utilization and conservation. In. Johnson, D. (ed.). Palm for human needs in Asia. The World Wide Fund for Nature (WWF) and The World Conservation Union (IUCN), Rotterdam: 37-73.

Rohlf, F.J. 1993. NTSYS-pc, numerical taxonomy and multivariate analysis system. Exeter Software, New York: $x+133$.
Sneath, P.H.A. and R.R. Sokal. 1973. Numerical taxonomy, the principles and practice of numerical classification. W.H. Freeman and Co., San Francisco: 573 p.

Stace, C.A. 1989. Plant taxonomy and biosystematics. Second editions. Cambridge University Press., Cambridge: vii + 264 p.

Uhl, N.W. and Dransfield, J. 1987. Genera palmarum, a classification of palms based on the work of Harold E. Moore, Jr. The Bailey Hortorium and The International Palm Society. Allen Press., Kansas: $x x i+610$ p.

Whitmore, T.C. 1985. Tropical rain forests of the Far East. Oxford University Press., Oxford: xvi + 352p.

Witono, J.R., J.P. Mogea, and S. Somadikarta. 2002. Pinanga in Java and Bali. Palms 46(4): 193-200 (in press). 